\title{
TEAMWORK IMPACT ON START-UP MANUFACTURING ENTERPRISE WORK PROVISION
}

\author{
Inese LŪSĒNA-EZERA ${ }^{1}$, Diāna LİDUMA ${ }^{2 *}$, Atis EGLIN̦Š-EGLĪTIS ${ }^{2}$ \\ ${ }^{I}$ Faculty of Management and Social Science, Institute of Management Science, Liepaja University, \\ 14 Lielā Street, LV 3400, Liepaja, Latvia \\ ${ }_{2}^{2}$ Institute of Management Science, University, Liepaja University, 14 Lielā Street, LV 3400, Liepaja, Latvia \\ ${ }^{*}$ E-mail:diana_liduma@inbox.lv
}

\begin{abstract}
Purpose - clarifying the current risks and organizational issues in start-up manufacturing enterprises in Latvia, to find out the impact of teamwork on work provision in Latvia start-up manufacturing enterprises.

Research methodology - to achieve the purpose of this study, a survey of 55 start-up entrepreneurs from fifteen Business Incubators of Investment and Development Agency of Latvia in 2018 was undertaken by an online questionnaire.

Findings - the results of the research have indicated that the lack of own team is one of the dominant start-up manufacturing enterprise work risks. Comparative analysis of data showed that mostly the entrepreneurs, who have started development of their business idea individually and whose enterprise's work is basically based on a singledecision making, have encountered the issue. However, the research outcomes revealed that provision of start-up manufacturing enterprise work outcomes is related to the teamwork factor - both belief in joint work, common understanding about the expected outcomes, mutual trust and support.
\end{abstract}

Research limitations - direct start-up enterprises, which have registered their activity in one of the sub-sectors of the NACE (Rev. 2) Group C "Manufacturing Industry" and receive the support provided by the Investment and Development Agency of Latvia Business Incubator for their start-up activity in Latvia, without exceeding a 4-year incubation period, have been chosen for the research.

Practical implications - the research outcomes point to the need of Business Incubators of Investment and Development of Latvia to provide not only tangible opportunities for start-up manufacturing enterprises for the business idea development during the incubation period, but also practical knowledge on team building during the business start-up process.

Originality/Value - Unlike other studies that are mostly focused on hard benefits in enterprises, as well as in start-ups, this is a specific research which provides insights on whether teamwork is recognized as an important factor of startup manufacturing companie work provision in relation to technological and external risks during the business start-up process and its work result achievement.

Keywords: start-up manufacturing enterprise, teamwork, risks, work provision.

JEL Classification: D23, L2, M10.

Conference topic: Contemporary Organizations Development Management.

\section{Introduction}

When starting a business, new entrepreneurs encounter a range of unsolved issues related to the legal, economic, funding, technological, market and competition risks, among which one is also finding an appropriate team of staff. According to the data of Latvian Start-up Association, about 300 start-ups have been registered in Latvia so far (Lejina, 2018) and Latvian Start-up Association's daily work experience confirms that the base of Latvian start-up failures is both the fact that the product does not have a buyer and also cash exhaustion. Also, low enthusiasm for teamwork and founder inability to overcome failures have been highlighted as problems (Lejina, 2018). The problems experienced by most of start-up founders, expressed in specialist opinions, repeat and are distinguished as one and the same. Just product, market and funding risks can be found traditionally among them and sometimes teamwork issues, too. Lettich (2018) lists 14 risk groups encountered by entrepreneurs (Capability Risk, Design Risk, Development Risk, Economic Risk, Economic Life Risk, Funding Risk, Legislative and Policy Risk, Maintenance 
Risk, Operations Risk, Procurement Risk, Research Risk, Technology Risk, Volume/ Demand Risk) and he mentions that risk awareness and consideration allow start-up founders to determine the direction of the company's development and growth. Management Risk is also placed among the mentioned risk groups, thus emphasizing directly the correlation between team's achievements and its awareness of risks and problems the start-up companies can encounter, or they have already encountered (Lettich, 2018). Having had several discussions with entrepreneurship initiators, entrepreneurs Houlihan and Harvey (2018) have concluded that amongst the range of factors such as Inadequate Testing, inability to get into the market and Lack of Persistence, just Team Incompatibility takes the second most mentioned cause of start-up failure. Also, in the research Top 20 Reasons Why High Tech Start-ups Fail carried out on the CB INSIGHTS platform, collating 101 start-up companie failure reasons, it has been revealed that in $23 \%$ of cases it has been a bad team, in $29 \%$ of cases insufficient means for business launch has been shown as the reason and for $42 \%$ of start-up companies it has been related to market problems (CB INSIGHTS, 2018). Studying the impact of factors during different start-up life cycles, Timonin, Vereshchagina, and Pliekhanova (2018) have discovered that just in the start-up's formation and designing stage wrong definition of market needs, lack of team's qualification, mutual understanding in team and lack of intangible assets provision move forward primarily as failures. Also, the Tallinn Founder Institute (the Founder Institute, 2018), when organizing the start-up participants sessions, have concluded that start-up founders do not have sufficient focus on qualitative indices teamwork dynamics, instead of that they mostly focus on the quantitative work indices.

Team formation in a manufacturing company can be justified with the fact that development of new products, implementation of innovations, acquisition of new technologies, quality solutions, a better understanding of market needs, implementation of work and increase of productivity in manufacturing companies work out better when working in a team. (Haringtone-Mackin, 1994; Maginn, 1994; Hellers, 2000; Ķēniņš Kings, 2002; Forands, 2003; Hamilton, Nickerson, \& Owan, 2003; West, 2004; Boning, Ichniowski, \& Shaw, 2007; Vīksna, 2009; Bikfalvi, 2011; Grant \& Hallam, 2016; etc.) Also, in manufacturing companies, teamwork, regarding organizational issues, helps to solve tasks restricted in time, facilitates work in case of joint project performance and proves right in the conditions when the same people have to be invited and used several times for a task accomplishment (Forands, 2003, p. 114). Simultaneously, work in a team provides much more creativity, exchange of ideas, faster reaction to changes, and dividing duties mutually, it is possible to carry out several tasks at the same time (Vīksna, 2009, p. 121).

Even though some authors studies reveal that high-risk teams are not formed big and they require special competencies for its participants (Hellerstedt, 2009), founders of start-up companies mostly look for the entrepreneur's spirit and belief in the business idea in their team members- participants who are able to adapt and develop together with the company, who like the start-up idea and are ready to take risks, are committed and enthusiastic to see their companies as outstanding (Al-Masri, 2017). According to Gulati and DeSantola (2016), it has been proved theoretically that founders of start-up enterprises start thinking about team formation only during the growth phase, unless the idea had already emerged in the peer group. In its turn, if a start-up company has been started together with several peers, the success can be more distinct and it is easier to recover after having faced diverse problems (Lejina, 2018).

Taking into account the constantly changing needs of start-up manufacturing enterprises, founders of start-up enterprises "manage weak people out of the company and bring in strong ones that can handle the next stage of growth" (Cohan, 2014). In fast start-up companies development conditions, the ability to learn from each other is also justified (Hellerstedt, 2009, p. 151; Al-Masri, 2017) and a high-performance team can be distinguished from other teams just by its goal, functioning, relationships, communication and learning (Management Extra, 2009, p. 40), obtaining also friendly relationships in the work environment and developing a sense of belonging to the company (West, 2004). Studying successful Swedish technology start-ups and their founders teams, Borgefors and Lahlou (2017) have concluded that efficient start-up teams have a common system of values, variety of personalities, competencies and experience. Moreover, they possess culture and vision as important aspects, since values acting as the uniting factor that drives cohesion and performance (Borgefors \& Lahlou, 2017). In addition, loyalty and resources are also considered as factors of success in a newly founded company (Wang \& Wu, 2012).

Due to expansion of organizations and encounter with new levels of complexities, start-up manufacturing enterprises need to state and assign tasks formally (Gulati \& DeSantola, 2016). Also, when thinking of specialists team formation, it is important to find not only the right skills, but also to assess the person's ability to integrate in the start-up culture (the Founder Institute, 2018). The potential team member has to be able to see the holistic perspective, but successful daily action is determined by the ability to solve conflicts and provide a skillful communication process in compliance with the start-up specifics (the Founder Institute, 2018).

Labunska, Prokopishyna and Iermachenko (2018, p. 216) emphasize the significance of start-up companies in new knowledge accumulation, innovative project development and innovative idea commercialization and, applying and developing teamwork, an opportunity is given to adapt faster to changes and solve problematic issues in a more creative way. The role of teamwork in manufacturing enterprises is also justified with the fact that "a start-up company is a venture that offers completely (revolutionary) new products (services), introduces new technologies or completely new channels for product promotion" (Labunska et al., 2018), and in such conditions where knowledge, skills and roles are mutually complimentary, it can be a crucial resource of potential in teamwork. 


\section{Research methodology and participants}

In order to find out the impact of teamwork on work provision and result achievement in Latvia start-up manufacturing enterprises, a survey of 55 start-up entrepreneurs from fifteen Business Incubators of Investment and Development Agency of Latvia in 2018 was undertaken by an online questionnaire. The start-up companies, participating actively in one of NACE $2^{\text {nd }}$ red. C-Group sub-branches "Manufacturing," were surveyed. The start-up entrepreneurs survey was carried out from June till August 2018 and an online questionnaire was developed to clarify:

- What are the main operational risks of manufacturing start-up enterprises?

- Which organizational issues have caused problems in manufacturing start-up enterprises operation/ ideas` implementation?

- What guarantees work outcomes of manufacturing start-up companies?

- To what extent the operational risks of manufacturing start-up enterprises, organizational problems and guarantee of work outcomes are related to the teamwork factor?

Microsoft Excel application was used to process the quantitative data of the research.

$64 \%$ start-up companies out of the manufacturing start-up companies involved in the research have been the clients of the business incubator for 1-2 years, 36\% of the companies have been in the incubator for less than 1 year. Most of the start-up companies (78\%) employ up to 5 employees in order to provide the expected offer. $59 \%$ of manufacturing start-up companies activity is directed towards both the local and international market. 54\% of manufacturing start-up companies produce according to the order.

The limitation of research is a direct start-up enterprise, which have registered their activity in one of the subsectors of the NACE (Rev. 2) Group C "Manufacturing Industry" and receive the support provided by the Investment and Development Agency of Latvia Business Incubator for their start-up activity in Latvia, without exceeding a 4-year incubation period, have been chosen for the research.

Taking into account the essence of the research, emphasizing the teamwork aspects in manufacturing start-up enterprises work provision, within the framework of the article the outcomes of the research have been analyzed from two points of view: 1) whether the start-up enterprises work provision is based on others involvement in the enterprise's work process/unilateral approach problem-solving? 2) who the start-up business concept originated? (only the start-up founder's idea/the idea originated together with friends, family or peers.)

\section{Research findings}

The provided theoretical overview has given an impression about the start-up companies risks, where amongst the technological, financial and external risks in the business start-up process the significance of teamwork and the most appropriate participants involvement in enterprises operation have been especially emphasized. Also within the empirical research carried out by the authors, finding out experience of 55 manufacturing start-up entrepreneurs from fifteen Business Incubators of Investment and Development Agency of Latvia, it has been revealed that not an insufficient funding, but rather just lack of teamwork has been acknowledged as the main risk in the start-up enterprise's work provision - it has been confirmed by all managers of start-up manufacturing enterprises in Latvia involved in the research (Table 1). Moreover, the lack of teamwork is also emphasized by the manufacturing start-up entrepreneurs indication to inappropriate staff $(20 \%)$ as one of the risks in their company's work provision. Regardless of the above mentioned, the risks of Latvian manufacturing start-up companies are also equally related to financial planning, clients attraction measures, as well as to the unclear situation regarding the national legislation in entrepreneurship issues. Due to the risk comparative analysis, it has been found out that the issue about inappropriate staff is more distinct among the manufacturing start-up enterprise managers whose company's work is based on a unilateral approach in problem solving (25\%) and in the start-up company formation the business idea has only been the current - in the research involved start-up company manager's idea (24\%). Analysing the comparative outcomes in Table 1, attention should also be paid to the fact that the managers of the start-up companies, who had generated the business idea together with other peers, have indicated "insufficient knowledge in entrepreneurship" (21\%) and "wrongly chosen goal for entrepreneurship" (11\%) (Table 1) as risks, which within the framework of this research emphasizes the significance of teammates in start-up company's work provision and development. Moreover, the issue of teamwork cannot be emphasized only formally, but rather by nature- in the context of team members competencies. In this respect, the above mentioned is confirmed by Borgefors and Lahlou's (2017, p. 78) opinion, emphasizing not only teamwork and team members previous experience as a formality, but especially highlighting just the significance of entrepreneurship experience in the founders team. 
Table 1. Risks related to manufacturing start-up companie activity (source: authors)

\begin{tabular}{|c|c|c|c|c|c|}
\hline \multirow[b]{2}{*}{$\begin{array}{l}\text { Risks of start-up company's activity related } \\
\text { to*: }\end{array}$} & \multirow[b]{2}{*}{$\begin{array}{l}\text { Total } \\
(\%)\end{array}$} & \multicolumn{2}{|c|}{$\begin{array}{l}\text { Currently the company's action is } \\
\text { based on: }\end{array}$} & \multicolumn{2}{|c|}{$\begin{array}{l}\text { How your business idea } \\
\text { originated? }\end{array}$} \\
\hline & & $\begin{array}{c}\text { Others involvement } \\
\text { in company's } \\
\text { operational process } \\
(\%)\end{array}$ & $\begin{array}{l}\text { Unilateral } \\
\text { problem } \\
\text { solving } \\
(\%)\end{array}$ & $\begin{array}{l}\text { Idea originated } \\
\text { together with } \\
\text { friends/family/colle } \\
\text { agues/peers }(\%)\end{array}$ & $\begin{array}{c}\text { It is only } \\
\text { my idea } \\
(\%)\end{array}$ \\
\hline Lack of own work team & 100 & 100 & 100 & 100 & 100 \\
\hline Insufficient funding & 51 & 61 & 44 & 50 & 56 \\
\hline $\begin{array}{l}\text { Inappropriate clients attraction measures } \\
\text { (marketing/sales activities) }\end{array}$ & 36 & 39 & 34 & 36 & 32 \\
\hline Unreasoned planning of finances & 27 & 30 & 25 & 29 & 28 \\
\hline Inappropriate staff & 20 & 13 & 25 & 18 & 24 \\
\hline Unclear national legislation & 20 & 17 & 22 & 11 & 28 \\
\hline $\begin{array}{l}\text { Insufficient knowledge in business } \\
\text { management }\end{array}$ & 16 & 13 & 19 & 21 & 12 \\
\hline Unexplored market demand & 15 & 9 & 19 & 14 & 12 \\
\hline Unclear international legislation & 15 & 22 & 9 & 11 & 16 \\
\hline Inability to solve bureaucratic processes & 15 & 22 & 9 & 11 & 20 \\
\hline Underrated competition & 13 & 17 & 9 & 21 & 4 \\
\hline Implementation of unsuitable technologies & 11 & 17 & 6 & 14 & 8 \\
\hline $\begin{array}{l}\text { Ignorance about operation of different } \\
\text { institutions which affect your business }\end{array}$ & 11 & 13 & 9 & 7 & 12 \\
\hline Wrongly chosen place of operation & 9 & 9 & 9 & 11 & 8 \\
\hline Wrongly chosen business partners & 9 & 0 & 16 & 7 & 12 \\
\hline Wrongly chosen goals for entrepreneurship & 5 & 13 & 0 & 11 & 0 \\
\hline Other & 4 & 9 & 0 & 7 & 0 \\
\hline Wrongly defined incubation goals & 2 & 0 & 3 & 0 & 4 \\
\hline $\begin{array}{l}\text { Inappropriate selection of the enterprise's } \\
\text { structure }\end{array}$ & 2 & 4 & 0 & 4 & 0 \\
\hline
\end{tabular}

*multiple response question.

According to the findings by Hellers (2000, p. 9), in general teamwork in manufacturing companies can "increase work productivity in a company, improve quality of production (Hellers, 2000, p. 9), whereas in the case of start-up enterprises a regular overview of own plans and execution strategy is very important on the base of own resources, as well as the choice of right time and prudent decisions, including participant involvement in the right relationship formation with people (Goyal, 2016). The research outcomes of Latvian manufacturing start-up companie managers carried out by the authors indicate directly to the above mentioned - for the lack of time and issues of the necessary staff attraction are revealed as the main problems of organizational nature in manufacturing start-up companie activity (mentioned by $100 \%$ of managers). $25 \%$ of manufacturing start-up companie managers have also acknowledged the problem of work division in compliance with employee competencies and responsibilities, whereas $23 \%$ of managers mention the lack of suitable peers as topical (Table 2). An interesting situation has been discovered when analyzing the research outcomes, taking into account 1) the "authors" and contemporaries of the business concept initiation and 2) other people's involvement in the manufacturing start-up companie work. According to the results collated in Table 2, the issue of peer attraction has been marked as important in both start-up enterprises, whose work is basically based on unilateral problem solving (28\%), and family, friends and other peer support in the business concept initiation process (29\%). The fact that work division, participant readiness to take responsibility and common decision making have appeared as the most problematic work organization and management processes in manufacturing start-up companies point to the need for the development of teamwork processes whose performance is based on several people's involvement in the concept implementation. A similar situation can also be noticed in the start-up company manager replies for whom the business idea had originated when being together with other people. Actually, the facts mentioned above indicate to both the manufacturing start-up company manager knowledge in management and possible lack of managerial skills and also that friends, family and acquaintence support at the beginning of the business concept does not mean its successful implementation, not yet. 
Table 2. Organizational issues causing problems in manufacturing start-up companie operation/ideas' implementation (source: authors)

\begin{tabular}{|c|c|c|c|c|c|}
\hline \multirow[b]{2}{*}{$\begin{array}{l}\text { Which organizational issues have } \\
\text { created problems in start-up } \\
\text { company's operation/plan } \\
\text { implementation? } *\end{array}$} & \multirow[b]{2}{*}{$\begin{array}{c}\text { Total } \\
(\%)\end{array}$} & \multicolumn{2}{|c|}{$\begin{array}{l}\text { Currently start-up company's } \\
\text { operation is basically based on: }\end{array}$} & \multicolumn{2}{|c|}{ How your idea originated? } \\
\hline & & $\begin{array}{l}\text { Other involvement } \\
\text { in company's } \\
\text { operational process } \\
\text { (\%) }\end{array}$ & $\begin{array}{l}\text { Unilateral } \\
\text { problem } \\
\text { solving } \\
(\%)\end{array}$ & $\begin{array}{c}\text { Idea originated } \\
\text { together with } \\
\text { friends/family/ } \\
\text { colleagues/peers } \\
(\%)\end{array}$ & $\begin{array}{l}\text { It is only } \\
\text { my idea } \\
(\%)\end{array}$ \\
\hline $\begin{array}{l}\text { Lack of time in relation to unilateral } \\
\text { problem-solving of all plans }\end{array}$ & 100 & 100 & 100 & 100 & 100 \\
\hline Attraction of necessary staff & 100 & 100 & 100 & 100 & 100 \\
\hline $\begin{array}{l}\text { Mutual work division in compliance } \\
\text { with competencies and functions to } \\
\text { be performed }\end{array}$ & 25 & 26 & 22 & 29 & 20 \\
\hline $\begin{array}{l}\text { Attraction of peers for business } \\
\text { development }\end{array}$ & 23 & 17 & 28 & 29 & 16 \\
\hline $\begin{array}{l}\text { Involved participants readiness to } \\
\text { take responsibility for the common } \\
\text { outcomes }\end{array}$ & 19 & 26 & 16 & 11 & 28 \\
\hline Joint decision-making & 19 & 26 & 13 & 21 & 16 \\
\hline Mutual trust in work performance & 13 & 17 & 9 & 11 & 16 \\
\hline $\begin{array}{l}\text { Lack of employees and participant } \\
\text { initiative }\end{array}$ & 11 & 17 & 6 & 11 & 12 \\
\hline Setting goals for future & 9 & 9 & 9 & 11 & 8 \\
\hline $\begin{array}{l}\text { Introduction of creative solutions in } \\
\text { the company }\end{array}$ & 8 & 9 & 6 & 14 & 0 \\
\hline $\begin{array}{l}\text { Granting freedom of action to } \\
\text { employees }\end{array}$ & 6 & 4 & 6 & 4 & 8 \\
\hline Other & 4 & 9 & 0 & 7 & 0 \\
\hline Generation of ideas & 4 & 0 & 6 & 4 & 4 \\
\hline $\begin{array}{l}\text { Communication and support for } \\
\text { manager's decision-making }\end{array}$ & 2 & 0 & 3 & 4 & 0 \\
\hline $\begin{array}{l}\text { Development of mutually supportive } \\
\text { atmosphere in the company }\end{array}$ & 2 & 0 & 3 & 4 & 0 \\
\hline
\end{tabular}

*multiple response question.

Overall, the results of the study presented in Table 2 are also in line with the views of the Latvian Association of Startup companies that, even though the business idea is definitely supported by friends, relatives, acquaintances initially, its vitality depends on whether the product is bought. At the same time, the base of a manufacturing start-up company's success is a good team, which does not only mean existence of good professionals - a programmer, marketing specialist, business developer, sales manager, but also the ability to cooperate, be flexible, respond quickly, ability to step quickly in another person's shoes, work for 24 hours or even change the business model essentially (Lejina, 2018).

Unfortunately, a totally different situation is created when finding out "what guarantees the manufacturing start-up enterprise's work outcomes?" (Figure 1). Regardless of the fact that $47 \%$ of the managers have mentioned the belief in common work in order to provide work outcomes as one of the most important teamwork drives, for $45 \%$ of the surveyed it is a precise division of functions, $44 \%$ of managers consider that work outcomes are guaranteed when all involved parties have common understanding about the expected outcomes, the results prove that staff's specialization, knowledge, competencies and even experience in the particular manufacturing process is important for only $25 \%$ of manufacturing start-up managers. Moreover, diversity of staff's knowledge, skills, thinking and experience as one of the factors for result achievement is considered by just $24 \%$ of the surveyed manufacturing start-up managers (Figure 1). Even more, a similar situation can be noticed regarding other teamwork processes, for instance, cooperation among manufacturing staff, creativity in problem-solving, employee skill to make common decisions - fewer than $30 \%$ of the surveyed managers relate it to work result provision, emphasizing just their own managerial skills to make decisions as the most essential (mentioned by $62 \%$ of start-up managers) (Figure 1). 


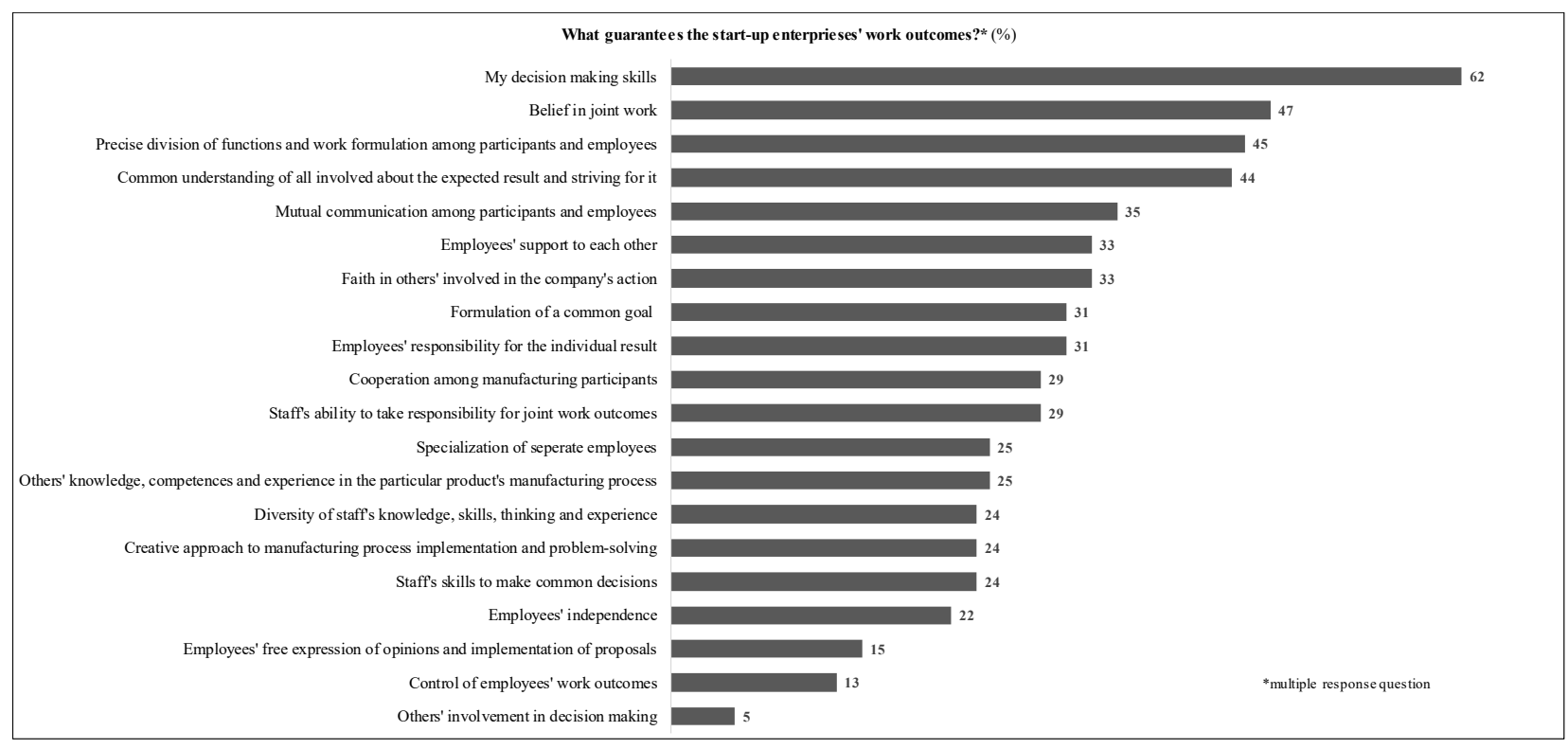

Figure 1. Processes of teamwork in manufacturing start-up enterprise's work result provision (source: authors)

Another situation has been revealed when comparing the research outcomes, taking into account the parties involved in problem-solving and the authors of the business concept creation (Table 3). In Table 3 the comparison of the collated outcomes shows that the staff's common understanding about the expected result, precise division of functions and the manager's skills to make decisions have been marked as the three main teamwork processes in the manufacturing start-up enterprise work outcome provision among the start-up managers who involve also other employees in problem-solving (marked by $70 \%$ of the surveyed) and the business idea has emerged being together with friends/family/ peers (marked by $57 \%$ of the surveyed). Comparing the start-up manager responses whose business work is mostly based on unilateral action, it was revealed that the managers of these enterprises consider just their managerial skills to make decisions as the most important in the result guarantee. However, at the same time also admitting one of the most essential elements of teamwork - belief in common work.

Proceeding with the question "what guarantees the start-up work outcomes?", a different situation can be noticed comparing the replies of the start-up companie managers in relation to such teamwork elements as staff's responsibility, individual employee specialization, employee knowledge, skills and experience and their diversity. As the outcomes reflected in Table 3 confirm, these elements are more distinct in the start-up companies which are based on other involvement in the start-up companie action and business concept initiation process, whereas an especially sharp distinction can be noticed just in the issue about the variety of the employee knowledge, skills, thinking and experience: if $48 \%$ of the start-up managers, in whose business processes others are also involved, the variety of employees is considered as an important factor in the work result guarantee, then regarding the managers who choose a unilateral approach in problem-solving and in whose business concept initiation other persons have not taken part, only $3-4 \%$ of the surveyed relate it to the start-up enterprise's work outcomes.

Table 3. Comparative analysis results of team processes in manufacturing start-up enterprise work outcomes guarantee (source: authors)

\begin{tabular}{|l|c|c|c|c|}
\hline \multicolumn{1}{|c|}{ What guarantees start-up company's work outcomes?* } & \multicolumn{2}{c|}{$\begin{array}{c}\text { Currently start-up company's } \\
\text { operation is basically based on: }\end{array}$} & \multicolumn{2}{c|}{$\begin{array}{c}\text { How your business idea } \\
\text { originated? }\end{array}$} \\
\hline My skills to make decisions & 70 & 50 & 57 & 64 \\
\hline Belief in joint work & 52 & 38 & 43 & 48 \\
\hline $\begin{array}{l}\text { Precise division of functions and work definition between } \\
\text { participants and staff }\end{array}$ & 70 & 22 & 57 & 28 \\
\hline $\begin{array}{l}\text { All involved people's common understanding about the } \\
\text { expected outcomes and striving for it }\end{array}$ & 70 & 22 & 57 & 28 \\
\hline Mutual communication between participants and staff & 39 & 25 & 32 & 32 \\
\hline Trust in others involved in the company's operation & 43 & 19 & 36 & 24 \\
\hline Participants and staff's support for other & 43 & 19 & 36 & 24 \\
\hline Participants and staff's responsibility for the individual result & 48 & 16 & 39 & 20 \\
\hline Definition of a common goal & 39 & 22 & 32 & 28 \\
\hline
\end{tabular}


End of Table 3

\begin{tabular}{|c|c|c|c|c|}
\hline \multirow{2}{*}{$\begin{array}{l}\text { What guarantees start-up company's work outcomes?* } \\
\text { Participants and staff's ability to take responsibility for joint } \\
\text { work outcomes }\end{array}$} & \multicolumn{2}{|c|}{$\begin{array}{l}\text { Currently start-up company's } \\
\text { operation is basically based on: }\end{array}$} & \multicolumn{2}{|c|}{$\begin{array}{l}\text { How your business idea } \\
\text { originated? }\end{array}$} \\
\hline & 35 & 22 & 29 & 28 \\
\hline Cooperation among manufacturing participants & 30 & 22 & 25 & 28 \\
\hline $\begin{array}{l}\text { Other knowledge, competencies and experience in the } \\
\text { particular product manufacturing process }\end{array}$ & 26 & 22 & 21 & 28 \\
\hline Specialization of separate employees and participants & 35 & 13 & 29 & 16 \\
\hline Participants and staff's skill to make common decisions & 39 & 9 & 32 & 12 \\
\hline $\begin{array}{l}\text { Creative approaches in manufacturing process } \\
\text { implementation and problem-solving }\end{array}$ & 35 & 13 & 29 & 16 \\
\hline $\begin{array}{l}\text { Participants and staff's knowledge, variety of skills, thinking } \\
\text { and experience }\end{array}$ & 48 & 3 & 39 & 4 \\
\hline Participants and staff's independence & 26 & 16 & 21 & 20 \\
\hline $\begin{array}{l}\text { Participants and staff's free opinion expression and } \\
\text { implementation of proposals }\end{array}$ & 22 & 3 & 18 & 4 \\
\hline Existing control of participants and staff's work outcomes & 13 & 9 & 11 & 12 \\
\hline Leader's involvement & 9 & 6 & 7 & 8 \\
\hline Other involvement in decision-making & 9 & 0 & 7 & 0 \\
\hline
\end{tabular}

*multiple response question.

Such a situation can be explained with the manufacturing enterprise's work specifics and functionality which determines not only the need for employee diversity, but also the level of this diversity in start-up enterprises, for not in all cases it justifies itself, possibly it will even cause some complications. For example, studying technology startups in Sweden, Borgefors and Lahlou (2017) have come to a conclusion that Swedish technology start-ups are diverse, thus gaining from synergy, which results from the diversity of personalities and opinions in the start-up. However, it is necessary to maintain diversity on a reasonable level, as the lack of the common can complicate cooperation among the ones involved in the start-up enterprise's action. And it, in its turn, points to the need to agree on values, create a common understanding about the expectations and constantly take care of the faith maintenance in joint work in the start-up company.

\section{Conclusions}

In the research, it has been revealed that in the context of work provision, the managers of start-up enterprises emphasize strongly their decision-making skills, which, undeniably, are essential in the company's management process. Nevertheless, it does not always mean common decision making or striving for it and successful achievement of outcomes. The obtained outcomes make us conclude that regardless of the fact whether other people are involved in the start-up enterprise's work processes - so on the one hand, it is thought about the necessary human resources in the business concept implementation, or the start-ups are still more orientated to their founder unilateral problem-solving, in the manufacturing start-up companies one can still feel more or less, but still a little the "selfreliance" tendency. The marked organizational problem "lack of time in relation to unilateral solution of all expectations", marked by all manufacturing start-up enterprise founders, is like a confirmation to it in the company's action provision and/or business concept implementation, and the fact that just a unilateral problem solving is the base for more than half of surveyed manufacturing start-up companies in Latvia. The above mentioned still does not say that work in teams is not necessary in such enterprises. It rather points to the need to develop the start-up founder managerial skills, the skill to delegate, acquire knowledge in team formation, also develop leadership, which has a significant role in teamwork.

Presenting a preconception in the theoretical part about the start-up companie risks, marking the role of teamwork and significance of the most suitable participant involvement among the technological, financial and external risks in the business kick-off process, the outcomes of the empirical research enable us to make a conclusion that teamwork and the elements and processes related to it are essential in the manufacturing start-up enterprise work result achievement. This was confirmed by start-up manager replies to the existing risks, mentioning the lack of team as the main risk, and not, e.g. insufficient funding, inappropriate implementation of marketing activities or inappropriate goal setting. Moreover, it has not been confirmed in the research that in the start-up enterprises, in whose action and/or business concept origination several people have been involved, the lack of own team has been 
felt less than in the start-ups whose activity is mostly focused on the founder shoulders only. The impact of the team factor is also reflected in the manufacturing start-up enterprise work outcomes guarantee, marking the belief in common work, work sharing, common understanding about the intended outcomes as the principal problems of organizational nature in the implementation of the start-up enterprise's intentions.

Within the framework of the research it has been found out that even though the existing risks, organizational problems and elements for work outcomes guarantee in the manufacturing start-up enterprise action in general mark the link with the teamwork factor, it is still essential to take into account that only the manufacturing start-up enterprise founder opinion has been reflected within the research, thus for a more profound research of the teamwork impact it would be necessary to involve also employees of start-up enterprises, as well as look at it in the context of start-up enterprise labour productivity.

\section{Disclosure statement}

Authors don`t have any competing financial, professional, or personal interests from other parties.

\section{References}

Al-Masri, S. (2017). Building your startup team: A guide to finding the perfect hire. Retrieved from https://www.entrepreneur.com/article/302689

Bikfalvi, A. (2011). Teamwork in production: Implementation, its determinants, and estimates for German manufacturing. Human Factors and Ergonomics in Manufacturing \& Service Industries, 21(3), 244-259. https://doi.org/10.1002/hfm.20230

Boning, B., Ichniowski, C., \& Shaw, K. (2007). Opportunity counts: teams and the effectiveness of production incentives. Journal of Labor Economics, 25(4), 613-650. https://doi.org/10.1086/519539

Borgefors, S., \& Lahlou, M. (2017). How founding teams and external investors drive success: Entrepreneurial guidance for Swedish technology startups and their investors (Master of Science Thesis). Stockholm, Sweden. Retrieved from http://kth.diva-portal.org/smash/get/diva2:1111009/FULLTEXT01.pdf

CB INSIGHTS. (2018). Top 20 reasons why startups fail. Retrieved from https://www.cbinsights.com/research/startup-failurereasons-top/

Cohan, P. (2014). The 3 biggest startup risks and how to manage them. Retrieved from https://www.inc.com/peter-cohan/the-3biggest-startup-risks-and-how-to-manage-them.html

Forands, I. (2003). Personāla vadība. Rīga: Latvijas izglīî̄ibas fonds (in Latvian).

Goyal, P. (2016). 5 ways to recover from startup failure. Retrieved from https://www.entrepreneur.com/article/283184

Grant, K. P., \& Hallam, C. R. A. (2016). Team performance in a lean manufacturing operation: It takes the will and a way to succeed. International Journal of Technology Management, 70(2-3), 177-192. https://doi.org/10.1504/IJTM.2016.075161

Gulati, R., \& DeSantola, A. (2016, March). Start-ups that last. Harvard Business Review, 54-61. Retrieved from https://hbr.org/2016/03/start-ups-that-last

Hamilton, B. H., Nickerson, J. A., \& Owan, H. (2012). Diversity and productivity in production teams. In A. Bryson (Ed.), Advances in the economic analysis of participatory and labor-managed firms (Vol. 13, pp. 99-138). Emerald Group Publishing Limited. https://doi.org/10.1108/S0885-3339(2012)0000013009

Haringtone-Mackin, D. (1994). The team building tool kit. NY: Amacom.

Houlihan, M., \& Harvey, B. (2018). The top 4 reasons startups fail, according to 14 international accelerators. Retrieved from https://www.entrepreneur.com/article/311064

Hellers, R. (2000). Darba grupas vadība. Rīga: Apgāds Zvaigzne ABC, SIA.

Hellerstedt, K. (2009). The Composition of New Venture Teams: Its Dynamics and Consequences (JIBS Dissertation Series No. 056.) Jönköping International Business School. ARK Tryckaren AB.

Ķēniņš Kings, G. (2002). Roku rokā. Ātrāk, augstāk, stiprāk. Rīga: Apgāds Biznesa partneri.

Labunska, S., Prokopishyna, O., \& Iermachenko, I. (2018). Cognitive modeling of the startup life cycle. Problemi Ekonomiki, 2(36), 214-220. Retrieved from http://www.problecon.com/export_pdf/problems-of-economy-2018-2_0-pages-214_220.pdf

Lejiṇa, D. (2018). Kāpēc bankrotē startapi Latvijāa? Retrieved from https://medium.com/@dagnijalejia/k\%C4\%81p\% $\overline{\mathrm{C}} 4 \% 93 \mathrm{c}-$ latvij\%C4\%81-bankrot\%C4\%93-startupi-2514d721d2ce

Lettich, T. (2018). 14 startup risks entrepreneurs should consider when launching their startup. Retrieved from https://fundingsage.com/14-startup-risks-entrepreneurs-should-consider/

Maginn, D. M. (1994). Efective teamwork. USA: McGrow-Hill.

Management Extra. (2009). Vadīt komandas. Rīga: Lietišķās informācijas dienests, SIA.

The Founder Institute. (2018). How to build an all-star startup team. Retrieved from https://fi.co/insight/how-to-build-an-all-starstartup-team

Timonin, O., Vereshchagina, G., \& Pliekhanova, T. (2018). Dynamics of the influence of risk factors taking into account marketing of start-up's life stage. Modern Economics, 9, 113-123. Retrieved from https://modecon.mnau.edu.ua/issue/92018/timonin.pdf

Vīksna, A. (2009). Savs bizness. Rīga: Lietišķais informācijas dienests, SIA.

Wang, C.-J., \& Wu, L.-Y. (2012). Team member commitments and start-up competitiveness. Journal of Business Research, 65(5), 708-715. https://doi.org/10.1016/j.jbusres.2011.04.004

West, M. (2004). Motivate teams, maximize success. San Francisco: Chronicle books LLC. 